\title{
Recenzja
}

\section{Marek Chmaj, Wiesław Skrzydło, System wyborczy w Rzeczypospolitej Polskiej, 5 wydanie, Wydawnictwo Wolters Kluwer, Warszawa 2015, ss. 196}

Książka zatytułowana „System wyborczy w Rzeczypospolitej Polskiej” jest uaktualnionym dziełem dwóch specjalistów w dziedzinie prawa konstytucyjnego. Wydana po raz pierwszy w 2002 r., przeszła szereg niezbędnych korekt i uaktualnień. Autorzy oddają w nasze ręce udoskonaloną publikację, podejmującą w sposób wnikliwy i szczegółowy problematykę systemu wyborczego w Polsce.

Rozdział pierwszy zatytułowany: „Zagadnienia ogólne” ma charakter wstępny. Przedstawiona została w nim problematyka istoty demokracji przedstawicielskiej, funkcje wyborów oraz w sposób wyczerpujący scharakteryzowano mandat przedstawicielski. Lektura ujętej w tym rozdziale treści pozwala czytelnikowi zapoznać się z podstawowymi zagadnieniami, które pozwalają na dalszym etapie lektury na prawidłowe zrozumienie poruszanych zagadnień oraz płynne poruszanie się po poszczególnych instytucjach sytemu wyborczego.

W rozdziale drugim pn. „Zasady polskiego prawa wyborczego” autorzy szeroko omówili obowiązujące aktualnie w Polsce zasady odnoszące się do prawa wyborczego. Treść publikacji wskazuje czytelnikowi, jakie prawa „rządzą” procesem wyborczym, a co więcej, pozwala na uzmysłowienie sobie obowiązków spoczywających na wszystkich uczestnikach i podmiotach procesu (aktu) wyborczego. 
Rozdział trzeci zatytułowany „Przepisy wspólne kodeksu wyborczego” ma za zadanie przybliżyć czytelnikowi tematykę obwodów głosowania i rejestrów wyborczych, głosowania, protestów wyborczych, administracji wyborczej, a także finansowania wyborów i kampanii wyborczej. Pomimo tego, że autorzy przedstawiają zagadnienia w sposób szeroki i kompleksowy, czytelnik może odczuć jednak mały niedosyt. Przedstawiono bowiem jedynie zarys problemu. Wydaje się, że wartym rozważenia byłoby poszerzenie przeprowadzonej analizy - zwłaszcza w kontekście sporej świeżości poruszanej problematyki - o wątek komparatystyczny, jak również dokonanie pewnej krytycznej (a być może i pozytywnej) oceny dotychczasowego zakresu stosowania przepisów.

W dalszej części publikacji autorzy odnoszą się w sposób szczegółowy do poszczególnych rodzajów aktów wyborczych. W rozdziale czwartym pn. „System wyborów do Sejmu” szczegółowo scharakteryzowany został system wyborczy do Sejmu, zaś rozdział piąty - „system wyborczy do Senatu” charakteryzuje rozwiązania właściwe dla drugiej z izb parlamentu. Kolejne rozdziały poświęcone zostały zagadnieniom z zakresu wyborów do Parlamentu Europejskiego (rozdział V), na urząd Prezydenta RP (rozdział VI), do organów stanowiących samorządu terytorialnego (rozdział VII), jak również na urząd wójta, burmistrza, prezydenta (rozdział VIII).

Uaktualnione, piąte wydanie podręcznika obejmuje szczegółowe omówienie zasad polskiego prawa wyborczego, przepisów wspólnych kodeksu wyborczego, jak również systemów dotyczących wyborów parlamentarnych, prezydenckich i samorządowych oraz do Parlamentu Europejskiego. Niewątpliwie książka ta może stać się nieocenionym źródłem wiedzy dla studentów prawa, politologii oraz kierunków pokrewnych, a także dla publicystów i osób ubiegających się o mandat przedstawicielski lub urząd.

Autorzy przekazali w pracy swoją wiedzę teoretyczną, jak i wiedzę praktyczną, na jaką składa się ich bogate, długoletnie doświadczenie. Opracowanie zostało napisane w sposób czytelny, zrozumiały dla odbiorcy, którym będzie zarówno osoba specjalizująca się w poruszanej tematyce, jak i czytelnik niekoniecznie zainteresowany systemem wyborczym w państwie. Pozwala ono zrozumieć złożoność i wielopłaszczyznowość zagadnienia. Problematyka systemu wyborczego w Rzeczypospolitej Polskiej została przez Autorów wnikliwie przeanalizowana, a następnie przekazana czytelnikowi w niezwy- 
kle przystępny sposób. Walor naukowy recenzowanej publikacji z pewnością nadaje ilość wykorzystanych źródeł wiedzy, jakże bogatej literatury przedmiotu. Autorzy posłużyli się tabelami oraz rycinami ilustrującymi poruszane aspekty w celu ułatwienia odbioru przekazywanych informacji.

Omawiana pozycja bardzo dobrze prezentuje się od strony edytorskiej. Poprawny język pracy, stylistyka oraz składnia sprawiają, iż publikację czyta się z lekkością i przyjemnością. Bezsprzeczną zaletą publikacji jest przedstawianie poszczególnych kwestii z dużą erudycją, a zarazem naukowym dystansem. $Z$ drugiej jednak strony nie sposób wskazać, że wyraźnie interesującym aspektem podnoszącym atrakcyjność oraz wartość merytoryczną rozważań byłoby odniesienie się w kilku przynajmniej aspektach do regulacji funkcjonujących w innych państwach europejskich. Oczywiście, zabieg taki skutkowałby zwiększeniem objętości publikacji i nieco odmiennym opracowaniem zagadnienia systemu wyborczego. Niemniej jednak, wątek porównawczy uwydatniłby szereg pozytywnych rozwiązań polskiego syste$\mathrm{mu}$, ale także naświetliłby te regulacje, które warto byłoby znowelizować lub nawet usunąć.

Reasumując, recenzowana książka jest niezwykle wartościowa z punktu widzenia naukowego, jak również dydaktycznego. Omawiane w niej zagadnienia, choć zawiłe i skomplikowane, przedstawione są w sposób czytelny i zrozumiały. Analiza przeprowadzona została z niekwestionowanym znawstwem poruszanych w niej zagadnień. Opracowane tematy cechuje rzetelność i wnikliwość. $Z$ uwagi na swoje walory merytoryczne, przydatność naukową i wartość poznawczą publikacja ta $\mathrm{z}$ całą pewnością stanie się cenną pozycją na rynku wydawniczym.

Mariusz Bidziński Szkoła Wyższa Psychologii Społecznej w Warszawie 